
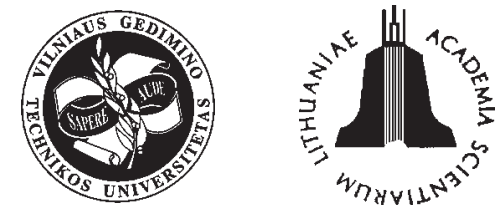

ISSN 1392-3730

JOURNAL OF CIVIL ENGINEERING AND MANAGEMENT

http:/www.jcem.vgtu.lt

2005, Vol XI, No 1, 49-55

\title{
STRESS-STRAIN CONCENTRATIONS IN HIGH-RISE STRUCTURE ELEMENTS AND MONOTONIC DISINTEGRATION UNDER THE INFLUENCE OF ENVIRONMENT CONTAMINATION
}

\author{
Valerijus Keras, Aurimas Valys, Jūratė Mockienė \\ Dept of Building Structures of Kaunas University of Technology, Studentu g. 48, LT-51367 Kaunas, Lithuania. \\ E-mail: daliusm@centras.lt
}

Received 17 March 2004; accepted 08 Nov 2004

\begin{abstract}
Abundance of metal masts and towers, their aging require to pay attention to corrosion phenomena and their after-affects. Special attention should be paid to the changes of structural elements strength and strain (induced by the environment aggressiveness) and to the phenomena of viability exhaustion of the whole system (dissipation). In these respects more premises for developing the second limit state formation are found first of all in separate mast elements and local chains, later in the whole structure. The article deals with the premises of developing chemical and electromagnetic contamination, its forecast and processes which could result from the above-mentioned pollution; it also analyses the destructive processes due to the pollution interaction with the material of structural elements as well as the consequences of aggressive contamination. Attention is also paid to the effect of the stress-strain concentrations around the corroded spots and their influence on the destruction evolution.
\end{abstract}

Keywords: masts, limit state, strength, strain, pollution, aggressiveness, corrosion, destruction, kinetics.

\section{Introduction}

Under the conditions of enlarging modern communication means, systems and their application space, the need for high-rise engineering structures (masts, towers etc) continuously increases [1]. Traditionally the construction of such structures is designed with regard to many independent factors: purpose, dislocation place, climate, technology, resources etc $[1,2]$. Often these factors are contradicting each other [3]. Quite significant problems for a masts designer there are also corrosion resistance [4], long time viability resources [5], stress-strain distributions into guys [6], lattice of structure [7, 8] or foundations [9] of the masts.

The investigations into the situations of service, accidents etc of such a kind of structures allow to reason that in the theory and practice of developing highrise structures there exist important, but still unsolved $[10,11]$ theoretical and practical problems. For instance, the fact should be kept in mind that when designing highrise structures not enough attention is paid to their service conditions and possible changes in apriori chosen calculation schemes as well as to the resulting processes connected with atmospheric pollution, humidity, electric discharges etc [12-14]. In case of high-rise engineering structures, the impact of chemical, electromagnetic and other kinds of pollution [14-16] may even be more dangerous in comparison with the dwelling and public houses. The height of the latter two kinds is usually much lower. Their principal bearing structures and joints are much better protected against outside impacts as well as against pollution activity of atmosphere. It shows the urgent character of the problem [17-20]. In addition, terroristic attacks against high-rise structures should be kept in mind. Geografically a special importance this problem obtains on the territory of the former Soviet Union and its satellites. For example, there is a number of such masts and towers along the frontiers of the former Soviet block in regions of Far East, Baltic countries etc. Especially it concerns the former military service objects left with no supervision. The masts and towers left with no supervision are very dangerous in regions subjected to earthquakes, wind gusts and other anomalies.

The investigation object is the destruction of the components of a mast under the impact of atmospheric pollution. The practical sample in this case is a metal lattice mast of $78 \mathrm{~m}$ height with cross-type lattice and three-level guys.

The work's aim is to show premises and kinetics of mast elements destruction under the action of aggressive environment and some other service factors.

Some more important peculiarities of the investigation may be described in this way:

- The calculation scheme of the structural object is produced by regarding the mast as a classical and 
high, flexible bar hinged on a foundation supported by guys under compressive, bending and rotational stresses. The joint of the support and bar is of hinge type. Taken together, it is a statically indeterminate system.

- An important premise of the limit states of analysed elements is a premature wear of structural joints, the increase of joint and support mobility because of wind impact, surroundings pollution by aggressive materials, icing, etc.

The methodic novelty is the application of operational planning methods for simulation modelling of the object disintegration processes.

The mast work has been modelled by the finite-element method. For calculations of the programme STAAD/ Pro 2000 was used.

\section{The sources of aggressive pollution}

It is most likely that in Lithuanian geographical situation the pollution flows (aggressive clouds) effecting high-rise structures may come from different localities. For instance:

- By prevailing south-west winds in a fraction of a year these clouds reach Lithuania from European industrial regions and Königsberg (Kaliningrad) district.

- The prevailing in winter winds of northern-eastern direction carry pollutants from Belorussian and Russian industrial regions and some military objects.

- Different winds and local atmospheric whirlwinds also bring local pollutants from Latvia. Especially harmful are chemically aggressive pollutants from the largest operating pollution sources (Kèdainiai, Jonava, Elektrènai, Mažeikiai, Naujoji Akmenè and similar objects).

In West European industrial countries strict limitations for atmospheric pollutants are being gradually introduced. Therefore in future the impact of atmospheric pollution on the longevity of Lithuanian high-rise structures should be considerably diminished. Nevertheless, the pollutants have been destroying for a long time (together with rain waters and otherwise) the presently used mast structures. It is possible that the atmospheric pollutants from Eastern countries will be rather considerable in future too. Therefore they are dangerous not only from the historical point of view, but also in the sense of prospective maintenance of appropriate constructions.

The long-running observation data on forming in Lithuanian territory flows of pollution and its clouds are plotted in the maps of territories with a polluted environment.

In addition, the eletromagnetic pollution in the atmosphere and in structural elements should be mentioned. Such a kind of pollution may have a considerable influence on the mast elements corrosion intensity and other indices [21, 22].
In communication systems, masts are applied in structures where the electric current flows. They are used as antennas. So their constructions propagate electromagnetic impulses themselves. Constructions of other objects work only as supports. Different communication equipment is mounted on them. Nevertheless, in this case direct electric current is not supplied to the structures. In spite of this, in the mast-bearing construction may also circulate the so-called vagabonding currents. They can be generated by the radioelectronic equipment supported by a tower structure, by the electromagnetic impulse reflections from the objects situated around the mast and by other influences.

Spontaneous wind gusts are sometimes also chracterised as pollution, as a pollution of the system of regular impacts. In such cases to the conception of influence system (space) of pollution are ascribed the earthquakes, karst phenomena, impact loadings resulting from the equipment starting up etc. Usually it means striving for underlying the exceptional character or irregularity of the above-mentioned loads and impacts [12, 14, 21, 22].

\section{Physical-mechanical processes produced by con- tamination of the elements of mast structure}

Alongside of normal aging of structural materials in course of time [23] and the phenomena of natural destruction, the processes of erosion and corrosion, stimulated by environment pollution, may have a considerable influence on the construction viability resource. In this respect the choice of mast design may be important. In respect of structural solution the mast stem must be solid (of tubular, box, compound or similar cross-section) or of lattice type, when the stem is connected by a lattice of different geometry (zigzag, triangular with horizontal elements, rhomboid, cross-type). For instance, the lattice shape is, at first glance, a quite elementary and wellknown structural solution. However, when analysing the possible impact of pollution, other advantages and disadvantages of lattices come to the fore. Besides, it is connected with a different liability to damage of the lattice elements in an aggressive environment and a quite different influence on these members damage and service safety.

The more welded seams or similar joints are hardly accessible to review repair and renovation parts and details are, the more danger of initial destruction exists in their work; and the more opportunities arise to damage their safety. These processes are directly connected with atmospheric pollution agents aggressive to the structural elements. This condition predetermines some changes in structural behaviour of mast materials (Fig 1). On the one hand, the metal under the influence of atmospheric pollution becomes more brittle in local or macro zones. On the other hand, around the corroded (pitted) zones, the stress-strain and deformations concentrations develop. At the beginning they appear at the microlevel as etched 
material dots - pitting. Later they join and stress-strain mezzo-concentrations develop. The latter can enlarge into macro-concentrations by developing corrosion and under the processes of erosion.

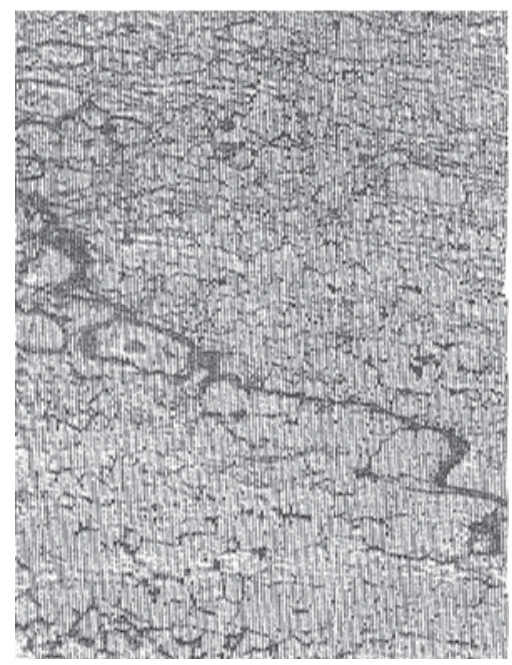

Fig 1. Damage aggregation process. The view of slow, monotonous disintegration of a welded seam (as a result of the common corrosion and wind pulsatile impact)

In their turn, the stress-strain concentrations inevitably develop in joints and details of the structure. It is because of structural factors, for instance, an uneven transmission of impacts and stresses from elements to elements. The genuine principles of structural elements joining in units and their work differ considerably from the idealised ones accepted in calculation schemes. Technological operations of installing joints also result in the stress-strain concentrations of technical origin. For guys, steel ropes are mostly applied. As a result of corrosion under the atmospheric pollution, the rope metal peculiarities may change, as well as their deformability, relaxation properties and at last the lossies of rope initial tension. The guys are anchored in reinforced concrete monolithic foundations or anchoring slabs. Concrete is less sensitive material to atmospheric pollution. Nevertheless, its composite parts are not inert to many elements and compounds of atmospheric pollution. Especially it is seen in a long-term perspective, when the pollution together with precipitation reach soil or the base of foundations.

The constructions of masts, including the long-term strength and other structural parameters of concrete, reinforced concrete structures and elements, depend largely on stress-strain changes, as well as on their redistribution and concentration foci development during service. Such cases occur rather often. When in some structural zones the stress-strain values increase, soon their results appear. These are stress-strain mezzo-concentrations, their interrelations and local crackings. In their turn, they influence the character of the stress-strain concentration kinetics. It is natural that, after an activisation of such a cracking, in some places different kinds of corrosion and foci, as well as errosion processes become active anew, and in some other spots they become more intensive. There are also cases when some cracks become close, for instance, when adjoining cracks develop more intensively.

The research shows that, under aggressive natural and technical media, different electromagnetic fields and vagabonding currents in metal structural elements may stimulate the electrochemical or electrolithic corrosion. The processes of electrochemical corrosion appeared to be more interesting. Data have been obtained concerning the intensification of atmospheric corrosion by electrochemical processes after forming a transparent humidity film (at a relative air humidity less than 100). Such a corrosion depends on humidity, temperature, atmospheric pollution level, chemical composition of pollutants etc. For instance, the presence of sulphuric gas (the product of burning coal or oil) in the atmosphere intensifies the above-mentioned atmospheric corrosion.

The electrochemical mechanisms increase greatly the corrosion processes of structural elements in different fissures, injured places, gaps between structural elements. In an acidic medium, the corrosion of slightly alloyed structural steels in cracks may be also intensified considerably by the development of galvanic pores. In their turn, such processes may become stronger in cracks by accumulating bacterial flora and similar sources of organic secretions. The corrosion products of structures operating in aggressive atmosphere are of a less cohesive material. They suffer severe erosion under the conditions of heavy rains, wind gusts etc. In this way the porosity and disintegration of the material surface continuosly increases. Different weaknesses as micro- and mezzo-concentrators develop. When uniting they make damage systems and weaknesses important for stressstrain concentrations and for work of certain structural units foreseeable in projects. The greatest problems connected with the viability of high-rise structures may arise in respect of their elements and materials corrosion results and the interaction of these results with wind impacts. Especially serious and undesirable consequences may be induced by the corrosion-erosion results, namely by the combinations and interrelations of structural weaknesses and spontaneous wind gusts $[10,11]$.

\section{Monotonous accumulation of structural damages under the influence of environment}

The possibility of different premature damage of the mast structural elements is evaluated by probabilistic parameters. The probability of dangerous coincidences (and consequences) is difficult to forecast in a general case. Therefore a large family (virtual multidimensional space) of potential destruction variants may develop. Sometimes it is called cursed Bellmann multi-dimensionality. However, by applying a systematic view and op- 
erational planning methods, by combining in complex with energetic conditions and criteria, the technology of immitational modelling of damage sequence becomes considerably simple [3]. It becomes possible and useful to reconstruct and forecast different possible situations, based on the principle "what would happen, if something" and using immitational modelling. Some of these procedures are not complicated in a computer variant. Their results are conveniently shown by strain-disintegration graphs.

As examples of immitational modelling results, it is possible to take some episodes of the investigation of $78 \mathrm{~m}$ height mast (with three-level guys and cross-sectional lattice) deformation and disintegration operations. In this case, the distribution of the mast element stresses by relieving its guys is discussed. It has been obtained when the guy 1154 of the third level did not operate (Fig 2) and the largest stress remained in the element 876. It was of $163,3 \mathrm{kN}$. It is less than the bearing capacity of $173,6 \mathrm{kN}$. Thus the mast resources in respect of first limit state are not exhausted yet. The displacements of the mast approach the second limit state $(74,8 \mathrm{~cm}$ less than $1 / 100=7800 / 100=78 \mathrm{~cm})$. The mast angular twist is $0,1841 \mathrm{rad}$ (10,5 degree).

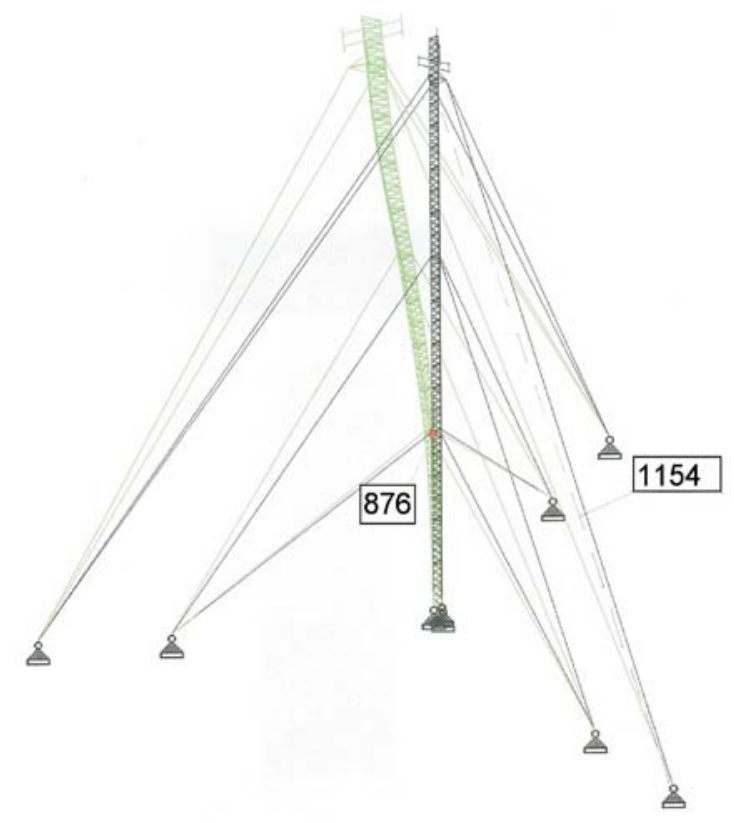

Fig 2. Mast displacements when the guy 1154 does not operate

When cutting off the work of the guy 1153 (Fig 3), the stress increases mostly in the element 875 . It becomes gradually larger than in the mast element 876 , the stress of which was the largest (during the work of the guy 1153). At last this stress reaches the value of $147,6 \mathrm{kN}$ (less than 173,6 kN element bearing capacity). Thus in this case the strength resource of the mostly loaded mast element has even increased. However, the displacements of the mast became too large, $83,98 \mathrm{~cm}$ more than $1 / 100=78 \mathrm{~cm}$. The condition of the second limit state is not satisfied. The mast angular twist becomes $0,1829 \mathrm{rad}=10,5$ degree.

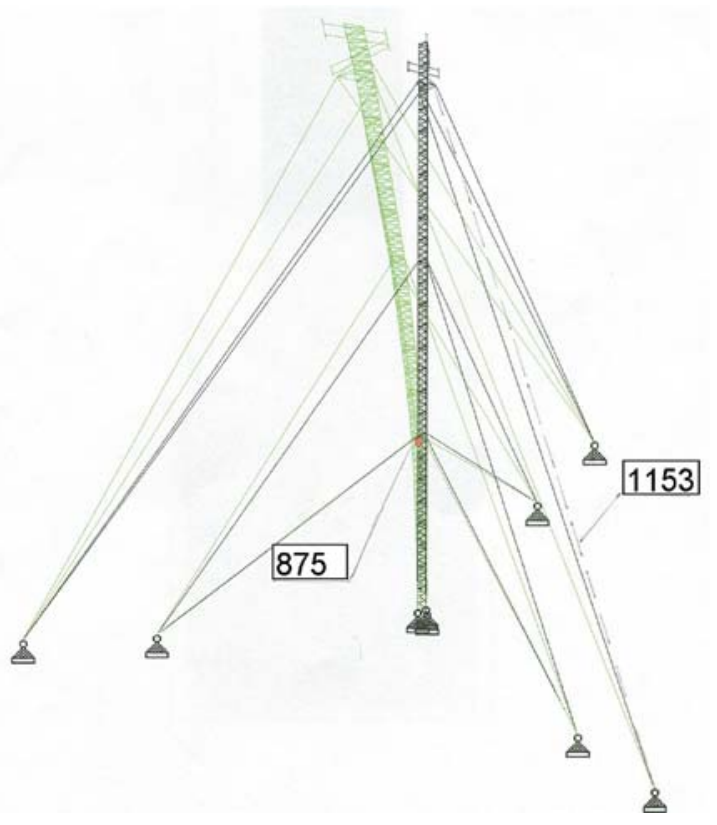

Fig 3. Mast displacements when the guy 1153 does not operate

When cutting off the work of the guy 1142, the stress increases mostly in element 770 (Fig 4). In this case it reaches $180,8 \mathrm{kN}$ (more than $173,6 \mathrm{kN}$ element bearing capacity). Thus the strength condition is not satisfied, the first limit state has been reached. However, the mast displacements satisfy the limitations: 53,2 less than $1 / 100=7800 / 100=78 \mathrm{~cm}$.

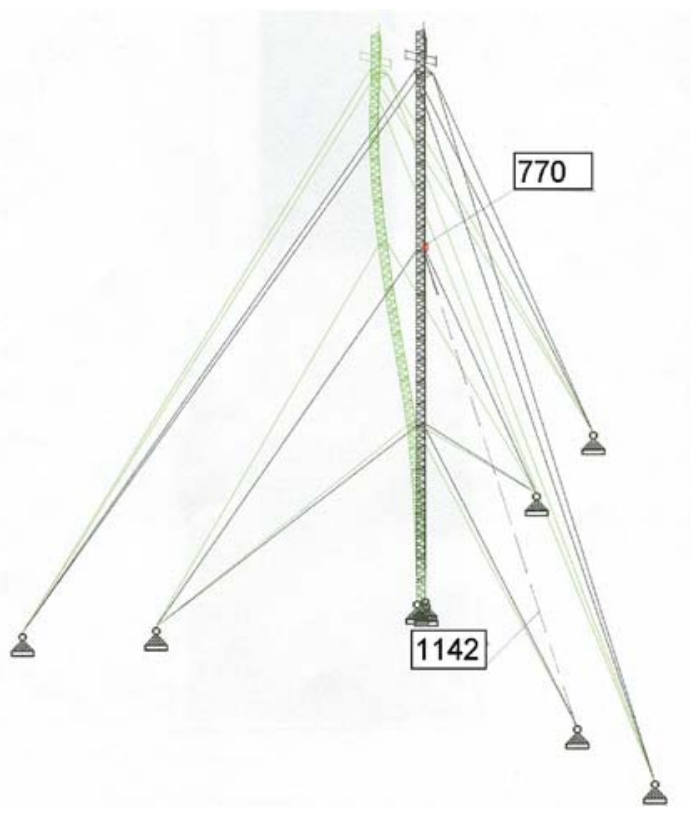

Fig 4. Mast displacements when the guy 1142 does not operate 
When releasing the second level guy 1142 up to $50 \%$ of initial design tension, the stress in it because of the initial stress from $7 \mathrm{kN}$ decreases up to $3,5 \mathrm{kN}$, and stresses from 78,25 Mpa up to 31,88 Mpa. In this case the highest stress appears in mast element 857 . Its strength is fully applied. Therefore a larger than $50 \%$ of the second level guy release threatens by an unstable work not only of the element, but also of the whole mast and at the beginning to formation of the first limit state.

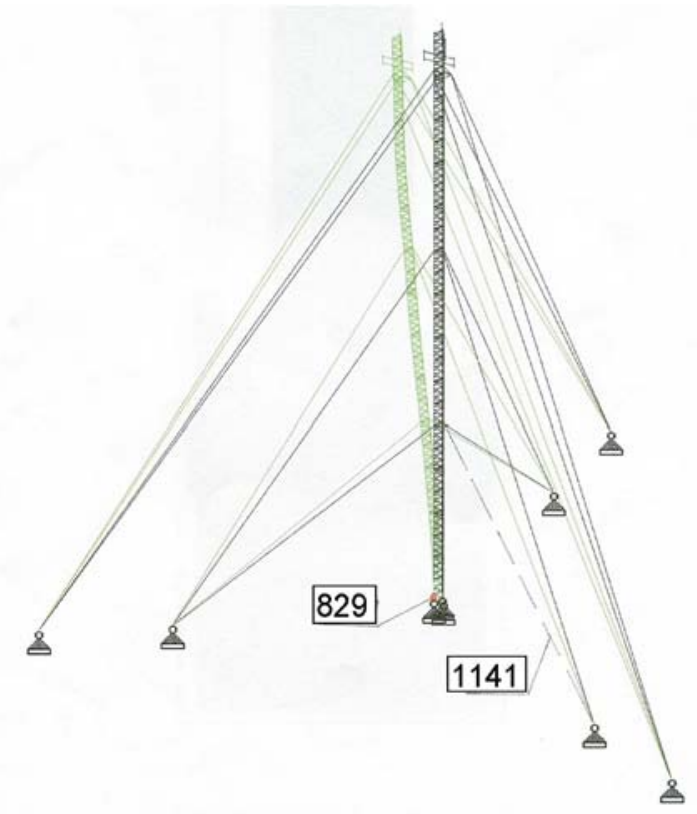

Fig 5. Mast displacements when the guy 1141 does not operate

Having stopped the first level guy 1141 working normally, the largest stress at the beginning in the element 876 is found in the element 826 (Fig 5). Its magnitude is by $209,4 \mathrm{kN}$ larger than $173,6 \mathrm{kN}$ (element bearing capacity). Thus, the first limit state in the bar is considerably exceeded. However, the mast displacements satisfy the second limit state criteria: $50,7 \mathrm{~cm}$ less than $\mathrm{l} /$ $100=7800 / 100=78 \mathrm{~cm}$.

When the first level guy 1141 is released by $35 \%$, its initial tension diminishes from $6 \mathrm{kN}$ to $3,9 \mathrm{kN}$, its stresses from 67,07 to $43,59 \mathrm{MPa}$. At this time the mast element 876 subjected to the largest stress practically fully applies the bearing capacity resources. Therefore, a larger than $35 \%$ of the above-mentioned guy release is dangerous in respect of the mast viability.

In the same way other variants of mast elements damages, their combinations and sequences have been analysed.

It can be underlined the importance of the striving for rationality and long-term reliability in different periods of buildings viability. Theoretical and practical investigations have disclosed [24] that not always, when optimising in respect of one criterion, it is possible to obtain solutions rational in other aspects (for example, in the aspect of viability taking into account special ser- vice conditions, aggressive environment etc). But it is possible to obtain rational solutions in a finite area of factors by application of multicriteria optimisation methods for truss designing [24]. The mast can be examined as variant of a statically undetermined high-rise truss with a special construction of supports: foundations and guys. Attempts have been made to find rational truss variants by applying different methods (method of proximity to an ideal point, Walds, Hurwitz's etc).

\section{Conclusions}

1. Environment pollutants aggressive to the materials of high-rise structures and spreading from many sources in West and East have been efecting for a long time the objects in several regions of post-Soviet area. In the near future the dislocation of pollution sources may change; nevertheless, aggressive pollution effects on high-rise structures in the past and future may be dangerous to their viability.

2. The stresses of many different-purpose masts left at present without supervision (for military, secrete services, aeronavigation etc purpose) are not adjusted to extreme effects of wind, storms etc. The following aspects must be taken into account:

the initial tension of the discussed models of the first level guys should be not less than $65 \%$. Mast chord stresses are rather sensitive to it. The mast construction can exceed both limit states;

the initial tension of the second level guys should not decrease up to $50 \%$ or more. It would be dangerous if some elements of the mast reach and surpass the first limit state;

after releasing the third level guy, some mast elements experience overloading. They may not surpass the limit states, however, the mast is effected by components of additional rotational loads. The mast top displacements may exceed restriction norms.

3. The complex effect of mast elements corrosion, erosion and tension release generates a large set of variants which is impossible to describe. But it can be reconstructed and graphically visualised by applying operational planning methods, disintegration conditions and criteria of fracture mechanics.

4. It is desirable an examination of the actual reliability (safety to perform) of the masts and towers; it is dangerous for surroundings and people.

5. It is desirable to examine a mast at designing stage for the influence of different kinds of pollution on its stresses and strains.

\section{References}

1. Vojevodin, A. A. Subdiagonal radio masts (Шпренгельные радиомачты). Moscow: Radio i Sviaz, 1981. 175 p. (in Russian). 
2. Savitskij, G. A. Calculation of the antenna structures (Расчет антенных сооружений). Moscow: Sviazizdat, 1978. 255 p. (in Russian).

3. Keras, V. K. About an integration of operations analysis methods into the means of strength calculation for automatisation of a flying machine design. In: Proceedings of all-union conference: Automatisation of investigations of strong capacity and longtime strength of flying apparatus (Сб. „Автоматизация исследований несущей способности и длительной прочности летательных аппаратов“). Oct, 20-24. Kharkow, 1975, p. 118-119 (in Russian).

4. Naumova, G. A.; Voronkova, G. V. The dependence of corrosion process kinetics on the element cross-section form. In: Transaction: Problems of strength of the elements and structures on interaction with aggressive surroundings (Сб. научн. тр. „Проблемы прочности элементов и конструкций, взаимодействующих с агрессивными средами“"). Saratov, 1994, p. 15-20 (in Russian).

5. Šulčius, A. Corrosion and safety of metals (Metalų korozija ir sauga). Kaunas: Technologija, 1999. 280 p. (in Lithuanian).

6. Jermekov, M. M.; Azhikenov, N. S.; Serikov, N. S. About stress-strain state of single circle spined rope. Petroleum trade industry bussines (Нефтепромысловое дело), № 1, 2002, p. 33-36 (in Russian).

7. Tzekhovoj, A.N.; Kumanin, V. I. The role of local stresses in the formation and development of destruction centres in time instrumental steel exploitation. Bulletin of machinery construction (Вестник машиностроения), № 11, 1994, p. 37-40 (in Russian).

8. Losert, H. Analyse eines ungewöhnlichen Schadenfalls im Stahlbau-Riserscheinungen in Bereichen geringer rechnerischer Beanspruchungen. Teil II. Erklärungen der Risursachen. Allianz Risiko und Sicherheit, No 33, 1993, S. $112-117$.

9. Keras, V.; Navickas, A. A. Alkali-aggregate reaction in concrete and its influence on the work of building elements and constructions. Journal of Civil Engineering and Management, Vol IX, Suppl 2. Vilnius: Technika, 2003, p. 126130.

10. Herrera, J. M. et al. A failure analysis case study structural steel design post collapse. Materials Characterisation, Vol 34, No 1. 1995, p. 57-61.

11. Herrera, J. M. et al A failure analysis case study of radio transmission tower. Materials Characterisation, Vol 34, No 1, 1995, p. 51-55.

12. Naumova, G. A. Analysis of experimental data of corrosion breaks kinetics in structures with protection films. In: Transaction: Nowadays problems of the non-linear mechanics of structures on interaction with aggressive environment (Сб. научн. тр. „Современные проблемы нелинейной механики конструкций, взаимодействующих с агрессивными средами“). Saratov: SGGU, 2000, p. 76-82 (in Russian).

13. Naumova, G. A. Calculating evaluation of stress deformation state and resourse of complex spatial structures with corrosion breaks accounting (Расчетная оценка напря- женно-деформированного состояния и ресурса сложных пространственных конструкций с учетом кинетики коррозионных повреждений). Summary of $\mathrm{PhD}$ Thesis for technical sciences doctor degree. Saratov state technical university. Saratov, 2001. 36 p. (in Russian).

14. Baranov, V. M.; Evstiuchin, N. A.; Kapralov, J. A.; Kulbach, A. A.; Surin, V. J.; Chugunov, S. A. A monitoring system of crack propagation in brittle materials. In: Transaction: Telecomunications and new information technologies (Сб. научн. тр. „Телекоммуникация и новые информационные технологии“), Vol 10. Moscow: MIFI, 2000, p. 69-70 (in Russian).

15. Sajdakov, J. N. Mechanical conception of destruction. In: Transactions of Perm state technology university: Aerocosmic technics (Вестник Пермского гос. техн. университета. „Аэрокосмическая техника“), No 13, 2002, p. 89-95 (in Russian).

16. Radish, J. V.; Kireev, A. C. Full-scale mathematic model of state of the metallic structures in service. Technical diagnosis and non-destructive control (Техническая диагностика и неразрушающий контроль), № 2, 2002, p. 3336 (in Russian).

17. Šapalas, V.; Kvedaras, A. K. Calculation of critical bending moment of metal columns subjected to pure bending. Journal of Civil Engineering and Management, Vol VIII, Suppl 1. Vilnius: Technika, 2002, p. 52-56 (in Lithuanian).

18. Juozaitis, J.; Pranevičius, J.; Šapalas, A. The influence of displacements and oscillations on behaviour of masts. Journal of Civil Engineering and Managament, Vol VIII, Suppl 1. Vilnius: Technika, 2000, p. 57-60 (in Lithuanian).

19. Šapalas, V.; Kvedaras, A. Stability of axially loaded tapered columns. Statyba (Civil Engineering), Vol VI, No 3. Vilnius: Technika, 2000, p. 158-161 (in Lithuanian).

20. Leonavičius, M.; Šukšta, M. Schakedown of bolts with a one-sided propagating crack. Journal of Civil Engineering and Management, Vol VIII, No 2. Vilnius: Technika, 2002, p. 104-107.

21. Brechet, I. Metallic structural materials in the nuclear environment: some problems illiustrating new methods. In: Transaction: Current researches. Phys. Academy of Sciences. Paris, No 7-8, 2002, p. 915-922.

22. Parkins, R. N.; Beavers, J. A. Some effect of strain rate on the transgranular stress corrosion cracking of ferritic steels in dilute near - neutral $-\mathrm{pH}$ solutions. Corrosion, No 3, 2003, p. 258-273.

23. Čibrekov, G. G.; Šafrai, S. D. Brittleness of low temperature action and means of its elimination. In: Transaction: Building structures and design of hydrotechnical buildings (Сб. научн. тр. „Строительные конструкции и расчет гидротехнических сооружений в условиях проведения экономических реформ“). Novosibirsk: NGAWT, 2002, p. 14-19 (in Russian).

24. Janušaitis, R.; Keras, V.; Mockienè, J. Development of methods for designing rational trusses. Journal of Civil Engineering and Managament, Vol IX, No 3. Vilnius: Technika, 2003, p. 192-197. 


\section{AUKŠTŲ STATINIŲ ELEMENTŲ DEFORMACIJŲ KONCENTRACIJOS BEI MONOTONIŠKAS IRIMAS,} VEIKIANT APLINKOS TARŠAI

V. Keras. A. Valys, J. Mockienė

\section{Santrauka}

Metalinių stiebu ir bokštų gausa bei jų senejjimas verčia skirti daugiau dėmesio jų korozijos apraiškoms ir pasekmėms. Ypač reikia atkreipti dėmesi i konstrukcijos elementų stiprumo bei deformatyvumo pokyčius ir visos sistemos gyvybingumo resursų išsekimo apraiškas (disipacija), kurie sietini su aplinkos agresyvumu. Šiuo atžvilgiu daugiau prielaidų yra antrajam ribiniam būviui susidaryti - iš pradžiu tam tikruose stiebo konstrukcijos elementuose bei lokalinèse grandyse, vèliau ir visoje konstrukcijoje. Nagrinejjamos statinio aplinkos cheminės bei elektromagnetinès taršos susidarymo prielaidos ir ju prognozès, procesai, kuriuos gali sukelti teršalai, stiebo darbo imitacinis modeliavimas, taršos sąveikos su konstrukcijos elementų medžiaga sukelti destruktyvūs procesai, agresyvios taršos procesų padariniai. Pažymèta įtempimų ir deformacijų koncentracijų aplink pažaidas veiksnio reikšmė destrukcijų raidai.

Raktažodžiai: stiebai, ribinis būvis, stiprumas, deformacija, aplinka, agresyvumas, korozija, irimas, kinetika.

Valerijus KERAS. Associate Professor (1968), Dept of Building Structures at Kaunas University of Technology (KTU), Lithuania. Doctor (1968). Research interests: fracture mechanics, concentration of stresses and strains, durability, destruction.

Aurimas VALYS. BSc (2001), MSc (2003). Research interests: viability-destruction processes of masts and towers, evaluation of design.

Jūratė STANKEVIČIŪTĖ-MOCKIENĖ. Post graduate student at the Dept of Building Structures of Kaunas University of Technology (KTU). MSc (1993). Since 1999 a PhD student at KTU. Research interests: steel structures, strength, durability, destruction, rational design. 